\title{
Biogenic silver nanoparticles synthesized from Piper longum fruit extract inhibit HIF-1 $\alpha /$ VEGF mediated angiogenesis in prostate cancer cells
}

\author{
Süleyman ILHAN ${ }^{1, *}$ (D), Çisil ÇAMLI PULAT ${ }^{2}$ (D) \\ ${ }^{1}$ Manisa Celal Bayar University, Faculty of Science and Letters, Department of Biology, Manisa / TURKEY \\ ${ }^{2}$ Manisa Celal Bayar University, Applied Science Research Center, Manisa / TURKEY
}

\begin{abstract}
In the present study, biogenic silver nanoparticles (PL-AgNPs) were synthesized by using Piper longum (PL) dried fruit extract and investigated the effect of PL-AgNPs on angiogenesis and signal transduction pathway of hypoxia-inducible factor alpha (HIF-1 $\alpha$ )/vascular endothelial growth factor (VEGF) on human prostate cancer cells. The prepared PL-AgNPs were characterized by ultraviolet-visible (UV-vis) spectroscopy, scanning electron microscopy (SEM), energy-dispersive X-ray spectroscopy (EDX) and dynamic light scattering (DLS) analysis. Potential cytotoxic and anti-angiogenic effects of PL-AgNPs were evaluated on PC3 and DU-145 prostate cancer cells. Cytotoxicity was evaluated by MTT assay. The antiangiogenic effect was investigated via a cell migration assay. Protein and mRNA levels of key angiogenesis related molecules such as VEGF and HIF-1 $\alpha$ were evaluated via ELISA and qRTPCR assays. UV-vis spectroscopy showed an absorbance peak at $450 \mathrm{~nm}$ confirming the PLAgNPs synthesis. Various characterization techniques revealed that the average size of synthesized PL-AgNPs was below $100 \mathrm{~nm}$. The cytotoxic effect was elevated in a concentration-dependent manner $(\mathrm{p}<0.05)$. The biosynthesized PL-AgNPs inhibited cell migration and reduced the levels of both protein and mRNA levels of VEGF and HIF-1 $\alpha$ in prostate cancer cells $(\mathrm{p}<0.05)$. Results revealed that the PL extract with $\mathrm{AgNO}_{3}$ nanoparticles may be a potential candidate for developing novel anticancer and antiangiogenic compounds for prostate cancer.
\end{abstract}

\section{Article info}

History:

Received: 21.11.2020

Accepted: 27.05.2021

Keywords:

Silver nanoparticles,

Prostate cancer,

VEGF,

HIF- $1 \alpha$,

Piper longum.

\section{Introduction}

Prostate cancer is a common malignancy among elderly men [1]. Although there are several treatment strategies including chemotherapy and radiotherapy, mortality is still high. Angiogenesis is one of the key processes for tumor development. Therefore, inhibition of angiogenesis is accepted as a hopeful treatment strategy for prostate cancer. Vascular endothelial cell growth factor (VEGF) is the most potent angiogenic promoter that induces vascular growth [2]. The levels of VEGF are modulated by hypoxia-inducible factor alpha (HIF-1 $\alpha$ ) which is expressed under the hypoxic microenvironment of the tumor [3]. Therefore, VEGF and HIF-1 $\alpha$ have become important targets of anti-tumor angiogenesis.

Currently, natural compounds are promising alternative sources for novel drug production. Among the natural compounds, plant extracts show high efficiency and easy availability [4]. Piper longum
Linn. (PL) belongs to the Piperaceae family. It is widely used as a spice and for traditional medicine mainly in Asia [5]. Piperlongumine and piperine have been identified as the major bioactive secondary metabolites of PL [6]. Antitumor, antioxidant and antibacterial effects of PL extracts and its alkaloid component piperine were investigated in several studies [7-10]. It was shown that PL has antioxidant activity against the free radical inducers, antiinflammatory activity, and it is used for several types of infections as well as respiratory system diseases [7, $11,12]$. Anticancer activity of PL extracts was also shown on various cancer cells $[8-10,13]$. The antimetastatic effect of piperine was shown on C57BL/6 mice [14]. It was also demonstrated that piperine can increase the cytotoxic effect of anti-cancer drugs for resistant cell lines like A-549/DDP and MCF-7/DOX [15]. The effect of pipernonaline as a piperine derivate 
was examined on PC-3 prostate cancer cells. The results demonstrated that pipernonaline has an apoptotic effect on PC-3 cell lines [16]. As demonstrated, PL holds great anticancer potential as a natural compound.

Nanotechnology is the world's fastest-growing manufacturing sector, with a never-ending quest for new nanomaterials and manufacturing methods. Because of their peculiar properties and possible applications in catalysis, photonics, optoelectronics, biological tagging, and pharmaceutical applications, metal nanoparticles have attracted a lot of interest in recent years. Using nanoparticles as a novel approach for improving antioxidant, anticancer and antimicrobial activities of natural compounds became the new promising source recently [18]. There are many in vitro studies showing different approaches for the synthesis of nanoparticles and the enhancing effect of these nanoparticles [19, 20]. However, exploration of the plant systems as the potential nano factories has heightened interest in the biological synthesis of nanoparticles. Further, the cytotoxic effect of PL leaf extract with silver nanoparticles was studied on Hep-2 cell lines and it was shown that the nanoparticles have a significant cytotoxic effect on the laryngeal carcinoma cells indicating that PL nanoparticles show potential for cancer cell cytotoxicity [8]. The present study was aimed at the synthesis of silver nanoparticles (PL-AgNPs) using Piper longum (PL) dried fruit extract and evaluation of their effect on hypoxiainducible factor alpha (HIF-1 $\alpha$ )/vascular endothelial growth factor (VEGF) signal transduction pathway on human PC-3 and DU-145 prostate cancer cells.

\section{Materials and Methods}

\subsection{Extraction of PL fruit}

The plant material was obtained from a local market and identified at Ege University, Department of Botany. Dried powder ( $5 \mathrm{~g}$ ) was extracted in absolute ethanol (EtOH) $(50 \mathrm{~mL})$ at room temperature, extracted for $60 \mathrm{~min}$ by ultra-sonication, and stored at room temperature $(0.1 \mathrm{~g} / \mathrm{mL})$. The concentration of EtOH was $<0.1 \%$ in all experiments and had no effect on cells.

\subsection{Biosynthesis of PL-AgNPs}

The biosynthesis of PL-AgNPs was carried out by mixing $34 \mathrm{mg}$ of $\mathrm{AgNO}_{3}(10 \mathrm{mM})$ with $45 \mathrm{~mL}$ of $\mathrm{H}_{2} \mathrm{O}$ $(18 \mathrm{M} \Omega)$ and $5 \mathrm{~mL}$ PL ethanolic extract. Then, the obtained solution was incubated at $90^{\circ} \mathrm{C}$ in a laboratory-grade microwave $(25 \mathrm{~min}$, at $300 \mathrm{~W}$ ) (CEM, Mars 6, USA). The reduction of $\mathrm{Ag}^{+}$to AgNPs is observed by the light greenish-brown color of the mixture. After synthesis, large particles were removed by filtering the samples through a $2.5 \mathrm{~mm}$ filter paper (Whatman No 5). The biosynthesis PL-AgNPs was centrifuged $\left(4{ }^{\circ} \mathrm{C}, 5000 \mathrm{xg}\right.$, ) for $10 \mathrm{~min}$. To discard plant extract residues, the solution was washed with double distilled water.

\subsection{Spectrophotometric characterization of PL- AgNPs}

To prevent unwanted additional photochemical reactions, all the reduction processes were carried out in the dark. The color of the solution changed to brownish-yellow which was observed by the naked eye. Then, to confirm the results, the so-called change was measured by UV-visible spectroscopy. The PLAgNPs solution was centrifuged at $12000 \times$ xg for $15 \mathrm{~min}$ at RT. After the centrifugation step, the solution was washed with distilled water. Then, the obtained PLAgNPs were collected in deionized water for other characterization steps.

\subsection{SEM-EDX and DLS analyses}

$\mathrm{AgNO}_{3}$ nanoparticles in PL extract were identified via Scanning Electron Microscope (SEM) and followed by Energy Dispersive X-ray Spectroscopy (EDX) analysis. A small drop of the sample was used on SEM stub and allowed to dry. After Au-Pd coating, SEM images were acquired with a secondary electron (SE) detector (Zeiss Gemini 500, Germany). EDX analysis was done to verify the elemental silver via EDAX, APEX $^{\text {TM }}$ Software for EDX. The PL-AgNPs were additionally analyzed by DLS which determines the size of colloidal scattering via the radiance of a molecule suspension having Brownian motion.

\subsection{Cell culture}

PC-3 (ATCC, CRL-1435) and DU-145 (ATCC, HTB81) cells were purchased from ATCC. Both prostate cancer cells were maintained in RPMI 1640 medium including L-glutamine (1\%), FBS (10\%), and penicillin-streptomycin solution (1\%) (Sigma) and incubated at $\mathrm{CO}_{2}$ incubator $\left(37^{\circ} \mathrm{C}\right.$ with $\left.5 \% \mathrm{CO}_{2}\right)$ during the experiments.

\subsection{MTT assay}

The viable cells were counted via trypan blue dye with Countess cell counter (Countess, Thermo Fisher Scientific, Massachusetts, USA) and were seeded at $1 \times 10^{5}$ cells/well. For attachment of cells, the plates were maintained for $24 \mathrm{~h}$ and then, treated with different extract concentrations $(10-100 \mu \mathrm{g} / \mathrm{mL})$ of PL ethanolic extract or PL-AgNPs solutions. After 24, 48 and $72 \mathrm{~h}$ incubations with the extract solutions, $20 \mu \mathrm{L}$ (10\% of the final volume) of MTT solution (Sigma) was pipetted to each well. After incubation for $4 \mathrm{~h}$ with 
MTT solution, cells were emptied and filled with 200 $\mu \mathrm{L}$ dimethyl sulfoxide (DMSO). Measurement of color change was carried out at $570 \mathrm{~nm}$ with the 690 $\mathrm{nm}$ reference wavelength by an ELISA reader (TECAN, Männedorf, Switzerland). The $\mathrm{IC}_{50}$ values of the extracts were calculated via Biosoft CalcuSyn 2.1 software (Biosoft, Cambridge, UK).

\subsection{Cell migration assay}

For assessing cell migration, the scratch assay protocol of Liang et al. (2007) was carried out. Briefly, $10^{5}$ cells/well were incubated for $24 \mathrm{~h}$ to obtain confluent monolayer cells. Then, a $200 \mu \mathrm{L}$ pipette tip was used to scratch the plate. Cells were exposed to the $\mathrm{IC}_{50}$ concentrations of PL-AgNPs ( $\mathrm{IC}_{50}$ value of PC-3 cells was $73.41 \mu \mathrm{g} / \mathrm{mL}$ and $38.53 \mu \mathrm{g} / \mathrm{mL}$ for DU-145). Closure of the scratched areas was measured for 24, 48 and $72 \mathrm{~h}$. Wells were monitored with an inverted microscope and photographed by Axiovision software (Zeiss, Germany).

\subsection{Measurement of VEGF and HIF-1 $\alpha$ levels}

Both VEGF and HIF-1 $\alpha$ protein levels were quantitated via ELISA assay (Biovision, VEGF cat\# K5363, HIF-1 $\alpha$ cat\#: E4285). Briefly, cell lysates were obtained by using lysis buffer, then $50 \mu \mathrm{L}$ cell lysates were transferred into antibody-coated 96 well plates. Then, streptavidin-HRP solution $(50 \mu \mathrm{l})$ and $10 \mu \mathrm{l}$ antibody (VEGF or HIF-1 $\alpha$ ) were added to each well. Then the sealing membrane was sealed and plates were incubated 60 minutes at $37^{\circ} \mathrm{C}$. After two washing steps with washing buffer, seconder antibodies were added to all wells and incubated at $37^{\circ} \mathrm{C}$ for $1 \mathrm{~h}$. Colorimetric reading was performed by ELISA reader at $450 \mathrm{~nm}$ (with $650 \mathrm{~nm}$ reference wavelength). Concentrations of both VEGF and HIF- $1 \alpha$ were calculated from the standard curves. The minimum detection limit of HIF$1 \alpha$ was $1 \mathrm{pg} / \mathrm{mL}$ and VEGF was $20 \mathrm{ng} / \mathrm{L}$.

\subsection{Quantitative real time PCR (qRT-PCR)}

The levels of VEGF and HIF-1 $\alpha$ mRNAs were quantified via qRT-PCR analysis. For the RNA extraction Trizol agent (Qiagen, USA) was used. First, cells were incubated with $1 \mathrm{~mL}$ Trizol for $5 \mathrm{~min}$ at RT. Obtained suspension was centrifuged at $12000 \mathrm{xg}$ for $20 \mathrm{~min}\left(\right.$ at $\left.4^{\circ} \mathrm{C}\right)$. After centrifugation, the supernatant was discarded and mixed with $1 \mathrm{~mL}$ isopropanol. Then, the suspension was incubated at $4{ }^{\circ} \mathrm{C}$ for $1 \mathrm{~h}$, and centrifugated at $12,000 \mathrm{~g}$ for $10 \mathrm{~min}$ for precipitation. The supernatant was removed and precipitants were dissolved in $20 \mu \mathrm{L}$ ultra-pure water. The obtained RNAs were checked for integrity and quality via agarose gel electrophoresis. cDNA was obtained from extracted total RNAs via using a commercial kit (Quantitect reverse transcription kit, Qiagen, USA).
The PCR was conducted in a mixture that was containing SYBR Green Master Mix $(12.5 \mu \mathrm{L}), \mathrm{H}_{2} \mathrm{O}$ $(10.5 \mu \mathrm{L}$, DNAase-RNase free) $1 \mu \mathrm{L}$ of primer stock $(20 \mu \mathrm{M})$, and $1 \mu \mathrm{L}$ cDNA for each primer (Qiagen, USA). The reaction was carried out using the Light Cycler 480 instrument $\left(10 \mathrm{~min}\right.$. at $95^{\circ} \mathrm{C}, 15 \mathrm{~s}$. at $95^{\circ} \mathrm{C}$, 1 min. $60^{\circ} \mathrm{C}, 40$ cycles) (Roche Applied Science, Germany).

Glyceraldehyde-3-phosphate dehydrogenase (GAP $\mathrm{DH})$ was used as a positive control. The primers of targeted genes were as follows: VEGF, forward 5'GCACCCATGGCAGAAGG-3' and reverse 5'CTCGATTGGATGGCAGTAGCT-3', HIF-1 $\alpha$ forward 5'-GATGTGGTTGTATTCGTG-3' and reverse 5'-ATCTCCTGCTTCTTTAGTC-3', GAPDH forward 5'-TGAAGGTCGGAGTCAACGGATT TGGT- $3^{\prime}$ and reverse 5'-CATGTGGGCCATGAG GTCCACCAC-3' (Microsynth, Germany).

\subsection{Statistical analysis}

Data was analyzed via GraphPad Prism software (USA). Two-way ANOVA followed by Dunnett's $t$ test was done to demonstrate significant differences between different treatments. ${ }^{*} p<0.05$ values were accepted as significant.

\section{Results}

\subsection{Confirmation of PL-AgNP formation via UV- vis spectroscopy}

First, the PL-AgNPs were characterized via the color change of the solution to brownish-yellow within $3 \mathrm{~min}$ after $\mathrm{AgNO}_{3}$ s were added. Then, the optical properties of PL-AgNPs were evaluated via UV-vis spectrophotometer. A peak occurring at $450 \mathrm{~nm}$ in the UV-Vis spectrum was characteristic for AgNPs and confirmed the formation of PL-AgNPs (Figure 1).

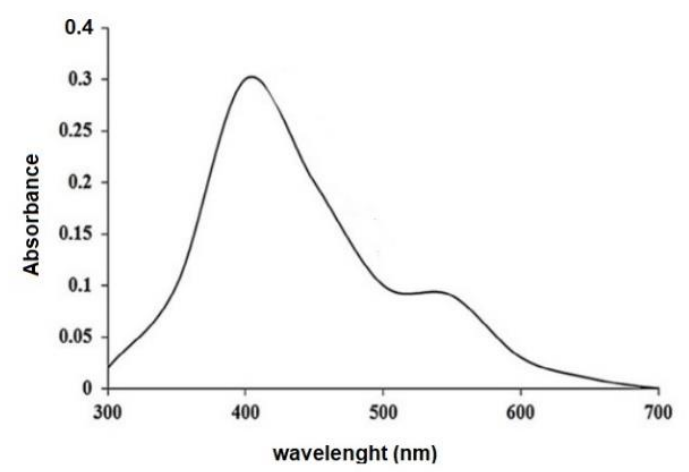

Figure 1. UV-visible spectrum recorded as a function of the reaction time of $1 \mathrm{mM} \mathrm{AgNO}_{3}$ solution with PL ethanolic extract. 


\subsection{SEM-EDX analysis}

The synthesized nanoparticles were scanned with SEM (Figure 2a). PL-AgNPs were also confirmed by using Energy Dispersive X-ray Spectroscopy (EDX) analysis. SEM image was recorded in $6 \mathrm{~mm}$ working distance (WD) with 5000 magnification. SE detector was used with $10 \mathrm{kV}$ electron high tension (EHT) in order to obtain the image. EDX data was acquired via EDAX, APEX ${ }^{\mathrm{TM}}$ Software and Ag L $\alpha$ signals were detected. An absorption peak at $3 \mathrm{keV}$ verified the elemental silvers in the nanoparticles. The EDX peaks corresponding to carbon, oxygen and sulfur indicated that AgNPs were properly capped by plant extract (Figure 2b).

$$
\text { a }
$$

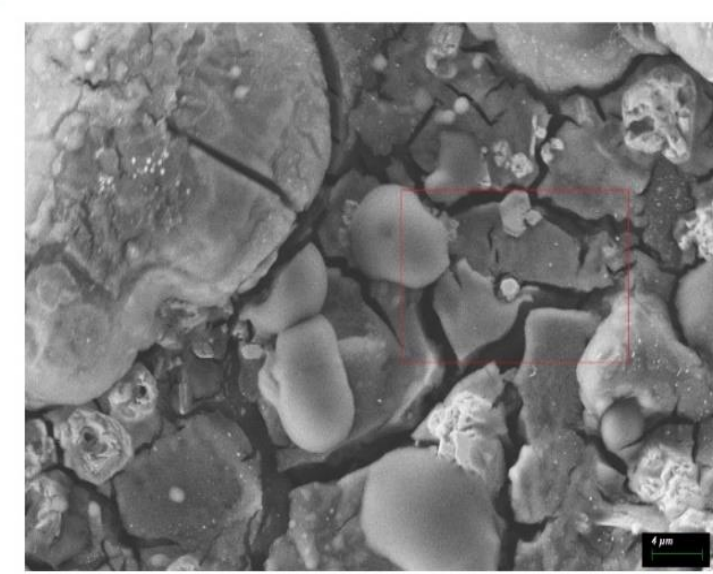

b

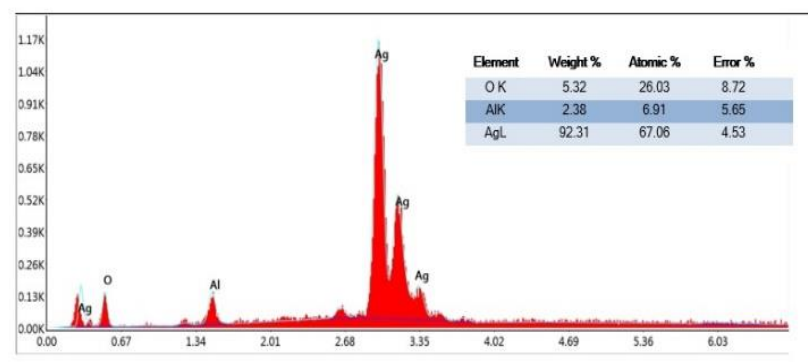

Figure 2. a) SEM image of PL extract with $\mathrm{AgNO}_{3}$ nanoparticles. (b) The area within the red square was used for SEM-EDX analysis and Ag signals were detected.

\subsection{Dynamic light scattering (DLS) analysis}

The impact of AgNPs was affected by the shape, particle size and size distribution as well as the composition. DLS analysis revealed that the mean diameters of PL-AgNPs in optimum conditions were approximately $11 \mathrm{~nm}$ (Std E: 5.5). Figure 3 shows the size distribution pattern of the suspension of PLAgNPs.

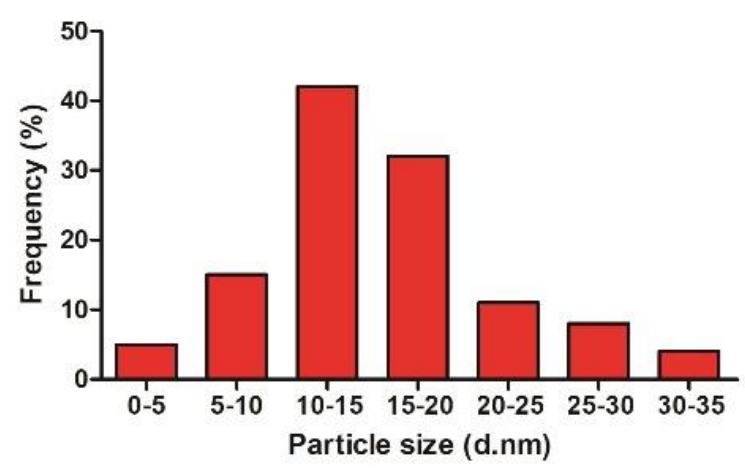

Figure 3. Dynamic light scattering of $\mathrm{AgNO}_{3}$ nanoparticles.

\subsection{Effects of PL ethanolic extract and PL-AgNPs on the viability of PC-3 and DU-145 cells}

The effects of both PL ethanolic extract and PL-AgNPs on cell viability were evaluated by MTT assay. While the PL ethanolic extract showed a very little cytotoxic effect on the prostate cancer cells at all tested concentrations, the extract with $\mathrm{AgNO}_{3}$ nanoparticles decreased the viability of both cancer cells dramatically at the same concentrations (Figures 4. and 5.) $(\mathrm{p}<0.05)$. The effect of PL-AgNPs was concentration-dependent but not time-dependent in both prostate cancer cells. The most effective time point for PL-AgNPs was determined as $48 \mathrm{~h}$ for both cell lines. As shown in Figure 4, there were 18\% and $30 \%$ reduction in the viability of PC-3 cells exposed to 80 and $100 \mu \mathrm{g} / \mathrm{mL}$ of PL ethanolic extract, respectively, as compared to the control group at $48 \mathrm{~h}$ $(\mathrm{p}<0.05)$, while there were $49 \%$ and $94 \%$ reduction in PC-3 cell viability exposed to 80 and $100 \mu \mathrm{g} / \mathrm{mL}$ of PLAgNPs, respectively, at $48 \mathrm{~h}(\mathrm{p}<0.05)$. In DU-145 cells, similar results were obtained (Figure 5). There were $10 \%$ and $14 \%$ reduction in the viability of DU145 cells exposed to 80 and $100 \mu \mathrm{g} / \mathrm{mL}$ of PL ethanolic extract respectively, as compared to the control group at $48 \mathrm{~h}(\mathrm{p}<0.05)$, while there were $97 \%$ and $98 \%$ reduction in DU-145 viability exposed to 80 and 100 $\mu \mathrm{g} / \mathrm{mL}$ of PL-AgNPs, respectively, at $48 \mathrm{~h}(\mathrm{p}<0.05)$. From the cell viability data, the calculated $\mathrm{IC}_{50}$ value of PC-3 cells was $73.41 \mu \mathrm{g} / \mathrm{mL}$ and $38.53 \mu \mathrm{g} / \mathrm{mL}$ for DU-145 cells which were treated with PL-AgNPs. 

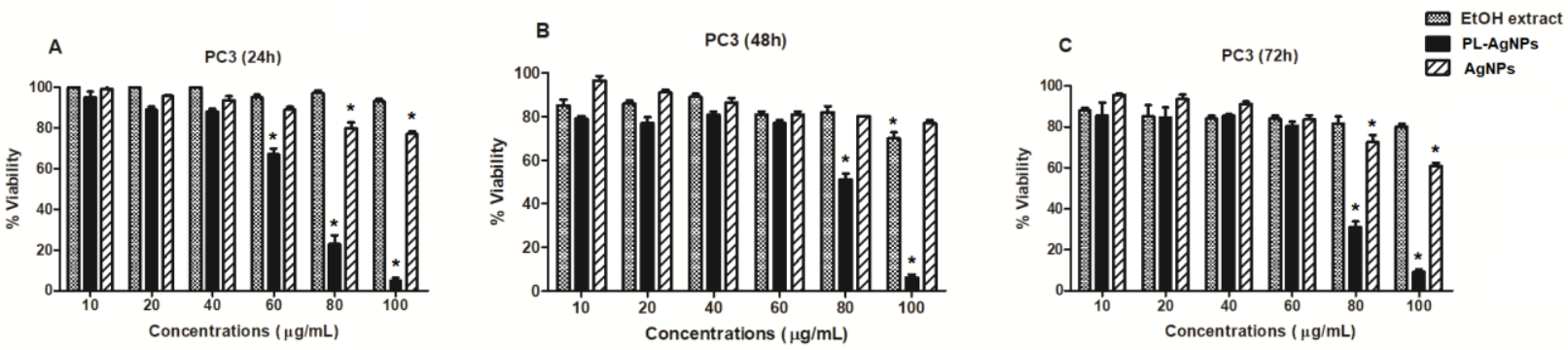

Figure 4. (A-C) Comparative effect of AgNPs, PL ethanolic extract and PL-AgNPs on PC-3 cell viability (*P<0.05, as compared to untreated controls).
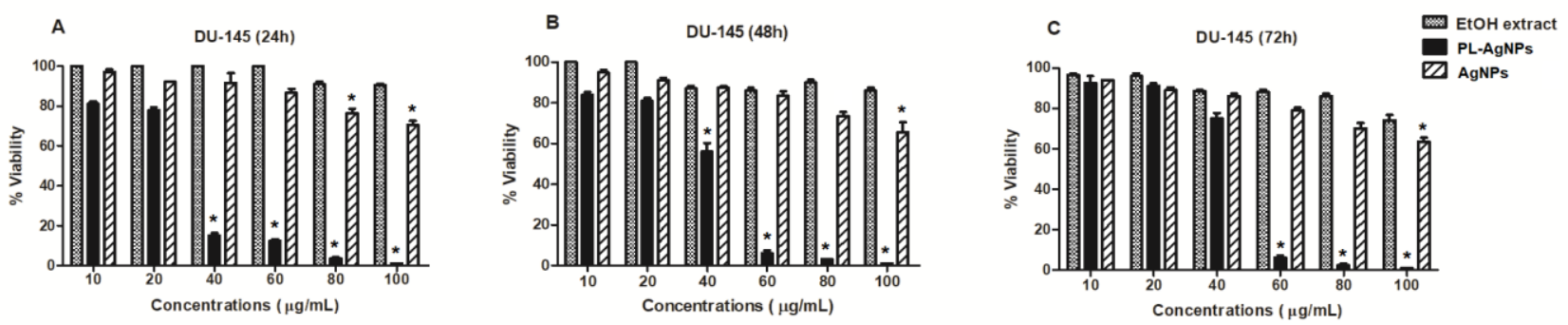

Figure 5. (A-C) Comparative effect of AgNPs, PL ethanolic extract and PL-AgNPs on DU-145 cell viability (*P<0.05, as compared to untreated controls).

\subsection{Effect of PL-AgNPs on cell migration}

Next, in vitro scratch assay was performed to evaluate the effect of PL-AgNPs on human prostate cancer cell motility. Treatment of both cells by PL-AgNPs resulted in a significant decrease in the cell motility (Figure 6.) suggesting the potential anti-angiogenic effects of the synthesized PL-AgNPs. When obtained data is compared with the control group, it is observed that PL-AgNPs has a considerably high wound healing effect at 48 and 72 h.

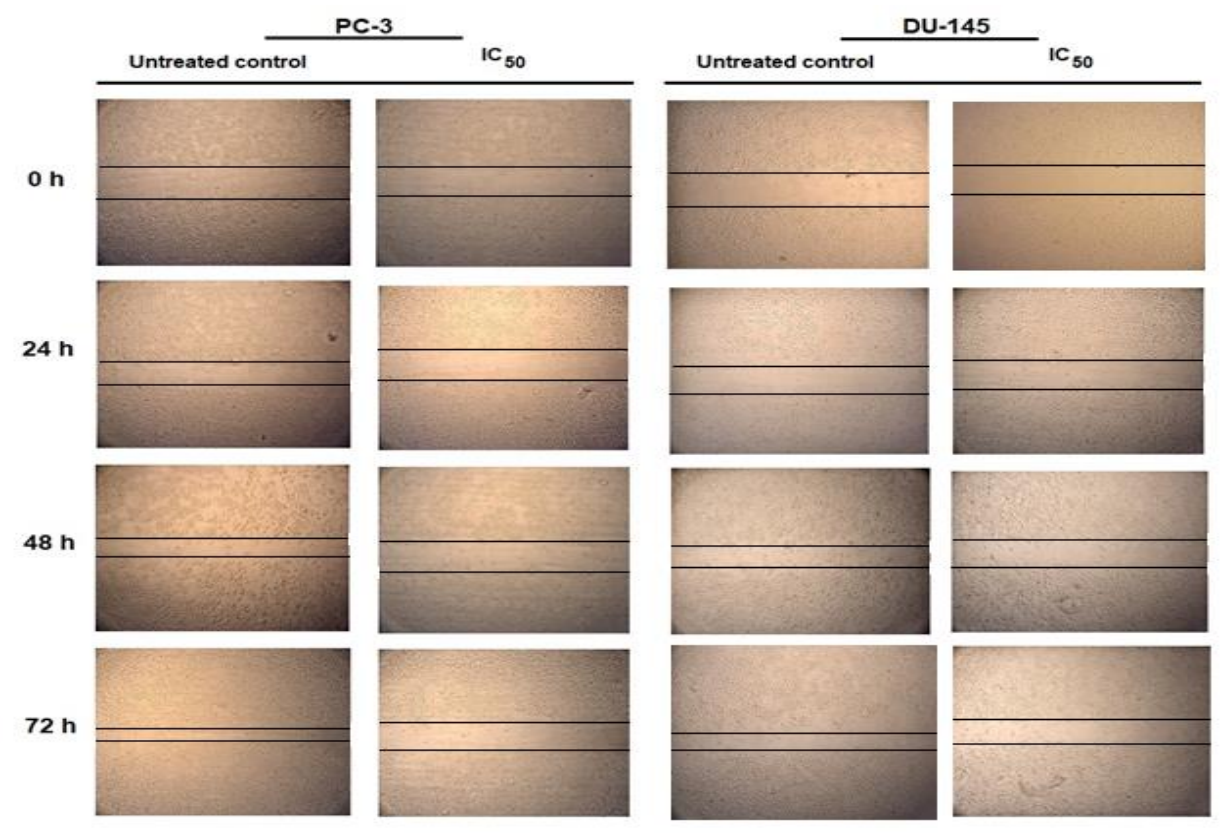

Figure 6. Effect of PL-AgNPs on the migration of PC-3 and DU-145 cells at 24, 48 and 72 h. The lines define the area lacking cells. 


\subsection{Evaluation of VEGF and HIF-1 $\alpha$ protein and mRNA levels}

The VEGF and HIF-1 $\alpha$ protein levels by PL-AgNPs treatment were evaluated via ELISA assay. The levels of both VEGF and HIF-1 $\alpha$ proteins were inhibited in a concentration dependent manner at $48 \mathrm{~h}$ in both prostate cancer cells $(\mathrm{p}<0.05)$ (Figure 7.).
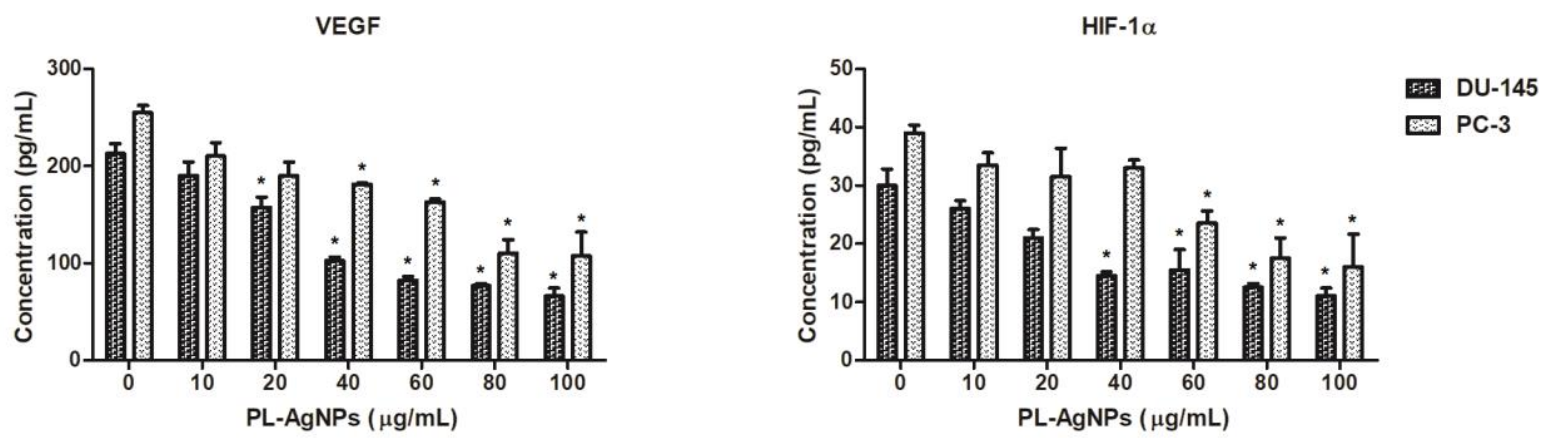

Figure 7. Levels of VEGF and HIF-1 $\alpha$ proteins by increasing concentrations of PL-AgNPs at $48 \mathrm{~h}$ in PC-3 and DU-145 cells $(* \mathrm{p}<0.05)$.

qRT-PCR was confirmed the inhibition of VEGF and HIF-1 $\alpha$ in both prostate cancer cells. The levels of VEGF and HIF- $1 \alpha$ mRNAs were reduced by 2.8 - and 3.2- fold in PC-3 prostate cancer cells treated with $73.41 \mu \mathrm{g} / \mathrm{mL}$ PL-AgNPs at $48 \mathrm{~h}(\mathrm{p}<0.05)$ (Figure 8.), while in DU-145 cells, VEGF and HIF-1 $\alpha$ levels were decreased by 2.4- and 2.8- fold exposed to 38.53 $\mu \mathrm{g} / \mathrm{mL}$ PL-AgNPs at $48 \mathrm{~h}(\mathrm{p}<0.05)$.

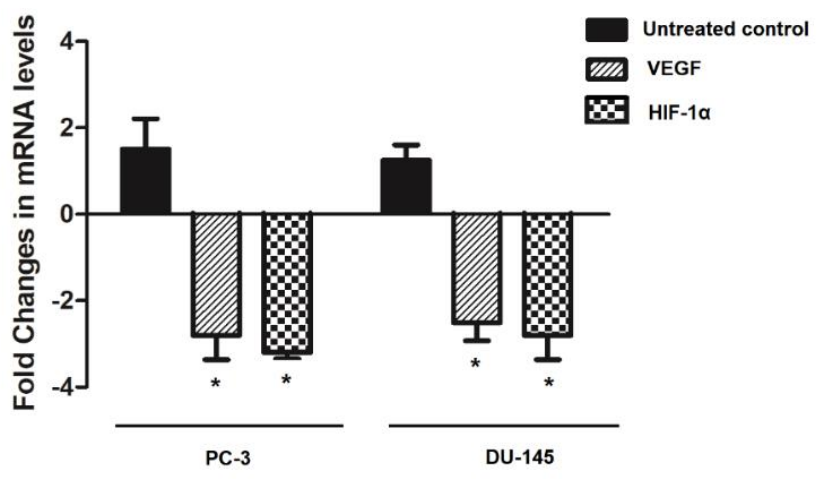

Figure 8. Inhibition of VEGF and HIF- $1 \alpha$ mRNA levels in PC-3 and DU-145 cells by PL-AgNPs at $48 \mathrm{~h}(\mathrm{p}<0.05)$.

\section{Discussion}

As a rapidly growing area, nanotechnology provided different insights to many other disciplines. Nanoparticles became the new promising source for biomedical studies with many different applications [21]. Synthesis of nanoparticles with the biosynthesis approach via using different organisms like yeast and bacteria have been studied closely [22-24]. On the other hand, using plant extracts with nanoparticles provided a new area since it also offers an enhancing effect of the plant extracts on cancer cells as an alternative treatment source. In this study, microwaveassisted and rapid phytosynthesis AgNPs using PL dried fruit extract are reported. In microwave heating, the nucleation process accelerates because of controlled high temperatures when the nanoparticles are initially formed. Thus, it is accepted as a very promising single step and easy approach for nanoparticle synthesis. Compared to the conventional methods, microwave heating provides higher degrees of crystallinity and more importantly small size nanoparticles.

It has been clearly shown that the green synthesis of nanoparticles having nontoxic properties by using plant extracts is a prevalent strategy and also provides natural capping agents. Results here showed the change in dark brown color indicating the generation of PL-AgNPs, which was further verified by spectroscopy. The UV spectra of the synthesized silver nanoparticles show the blue shift of the absorption band by increasing PL-AgNPs concentration. These results indicate that the PL-AgNPs were successfully developed from the extract solution, indicating that the $\mathrm{Ag}^{+}$has been reduced to $\mathrm{Ag}^{0}$. Secondary metabolites and other constituents such as proteins of the extract affect the reducing potential of nanoparticle formation 
[25]. These metabolites broaden the plasmon band as they can be read at the same spectrophotometric wavelengths. SPR of Ag can be read at $450 \mathrm{~nm}$. Mie theory claims that nanoparticles display a single SPR band. If the diversity of the particle shapes expands, the number of peaks also increases [26]. The size and morphology of PL-AgNPs have been also evaluated by SEM and EDX analysis. Then Ag signals were detected via APEX $^{\mathrm{TM}}$ Software. The EDX signals confirmed the abundance of silver elements in the synthesized PL-AgNPs. The size of the tested PLAgNPs was approximately $19-125 \mathrm{~nm}$.

Effects of $P L$ on several diseases have been reported [7]. Especially studies on anti-cancer activity attract attention [16, 27]. Synthesis of silver nanoparticles using PL leaf extract has been reported many times in the literature. Jacob et al. investigated its cytotoxic effect on human larynx epithelioma cancer (HEp-2) cell lines and the $\mathrm{IC}_{50}$ value was calculated as 31.25 $\mu \mathrm{g} / \mathrm{mL}$ at $24 \mathrm{~h}$ [8]. In another study, AgNPs using PL leaf extract were found to be cytotoxic against HeLa cervical cancer cell line. $\mathrm{IC}_{50}$ values were 221.4, 35.6, $17.8,12.9$ and $8.8 \mu \mathrm{g} / \mathrm{mL}$ after $24 \mathrm{~h}$ treatment for hexane, chloroform, ethyl acetate, methanol and aqueous extracts, respectively. Different from the literature, in this study, the effect of PL dried fruit extract on PC-3 and DU-145 cells was investigated and compared with the existence of $\mathrm{AgNO}_{3}$ nanoparticles. The $\mathrm{IC}_{50}$ values were $73.41 \mu \mathrm{g} / \mathrm{mL}$ and $38.53 \mu \mathrm{g} / \mathrm{mL}$ in PC-3 and DU-145 cells at $48 \mathrm{~h}$, respectively, which were higher than the PL leaf extract nanoparticles. Since it has been known that PL extract is cytotoxic on prostate cancer cells, the concentrations were kept low $(10-100 \mu \mathrm{g} / \mathrm{mL})$ to identify the enhancing effect of $\mathrm{AgNO}_{3}$ nanoparticles. It was shown that while PL extract was not effective on these low concentrations, the presence of $\mathrm{AgNO}_{3}$ nanoparticles along with PL extract increased the effect of cytotoxicity.

Angiogenesis, the generating of new vessels, has a vital role in tumor growth, metastasis, and invasion. Thus, it became an important target for cancer therapy [28]. PL-AgNPs inhibited cell migration of prostate cancer cells and decreased the levels of some key molecules having vital roles in angiogenic regulation. Vascular endothelial growth factors (VEGFs) are the main players in the angiogenesis of tumors [29, 30]. The primary stimulator of angiogenesis is hypoxia which induces hypoxia-inducible factors (HIFs) activating VEGF transcription. HIF- $1 \alpha$ is the key molecule that responds to hypoxia and is expressed highly in more than $70 \%$ of human cancers [31]. By exposure to PL AgNPs, the expression levels of VEGF and HIF-1 $\alpha$ were decreased in prostate cancer cells. Inhibition of cell migration and reduction of the most potent angiogenic regulator molecules may explain one of the most important mechanisms of the antitumor effects of PL AgNPs.

This is the first study demonstrating the microwave assisted synthesis and characterization of AgNPs from PL dried fruit extract. The characteristics of the biosynthesized PL-AgNPs were measured by different methods. Combining $\mathrm{AgNO}_{3}$ nanoparticles with $\mathrm{PL}$ dried fruit extract remarkably increased the effect of the ethanolic extract on prostate cancer cells. Moreover, inhibition of cell migration and reduction of the key angiogenic molecules may represent one of the most important mechanisms of its antitumor effect. These results showed that combining PL extract with $\mathrm{AgNO}_{3}$ nanoparticles could be a potential candidate as a novel anticancer nanomedicine approach for prostate cancer.

\section{Acknowledgments}

The authors wish to thank Serdar Gültekin for helping with the preparation of silver nanoparticles. The experiments in this paper were partially performed at Manisa Celal Bayar University (Turkey)- Applied Science and Research Center (DEFAM).

\section{Conflict of Interest}

The authors stated that did not have conflict of interests.

\section{References}

[1] Bray F., Ferlay J., Soerjomataram I., Siegel R.L., Torre L.A., Jemal A., Global cancer statistics 2018: GLOBOCAN estimates of incidence and mortality worldwide for 36 cancers in 185 countries, CA. Cancer J. Clin., 68(6) (2018) 394424

[2] Paduch R., The role of lymphangiogenesis and angiogenesis in tumor metastasis, Cell. Oncol., 39(5) (2016) 397-410

[3] Ahn G.O., Seita J., Hong B.J., Kim Y.E., Bok S., Lee C.J., et al., Transcriptional activation of hypoxia-inducible factor-1 (HIF-1) in myeloid cells promotes angiogenesis through VEGF and S100A8, Proc. Natl. Acad. Sci. U. S. A., 11(7) (2014) 2698-2703.

[4] Cragg G.M., Newman D.J., Natural products: A continuing source of novel drug leads, Biochim. Biophys. Acta - Gen. Subj., 1830(6) (2013) 36703695. 
[5] Ahmad N., Fazal H., Abbasi B.H., Farooq S., Ali M., Khan M.A., Biological role of Piper nigrum L. (Black pepper): A review, Asian Pac. J. Trop. Biomed., 2012(1) (2012) 1945-1953

[6] Liu H.-L., Luo R., Chen X.-Q., Ba Y.-Y., Zheng L., Guo W.-W., et al., Identification and simultaneous quantification of five alkaloids in Piper longum L. by HPLC-ESI-MSn and UFLCESI-MS/MS and their application to Piper nigrum L., Food Chem., 177 (2015) 191-196

[7] Kumar S., Kamboj J., Suman, Sharma S., Overview for Various Aspects of the Health Benefits of Piper Longum Linn. Fruit, $J$. Acupunct. Meridian Stud., 4(2) (2011) 134-140

[8] Justin Packia Jacob S., Finub J.S., Narayanan A., Synthesis of silver nanoparticles using Piper longum leaf extracts and its cytotoxic activity against Hep-2 cell line, Colloids Surfaces B Biointerfaces, 91(1) (2012) 212-214.

[9] Sunila E.S., Kuttan G., Immunomodulatory and antitumor activity of Piper longum Linn. and piperine, J. Ethnopharmacol., 90(2-3) (2004) 339-346.

[10] Sruthi D., John Zachariah T., In vitro antioxidant activity and cytotoxicity of sequential extracts from selected black pepper (Piper nigrum L.) varieties and Piper species, Int. Food Res. J., 24(1) (2017) 75-85.

[11] Kumar S., Arya P., Mukherjee C., Singh B.K., Singh N., Parmar V.S., et al., Novel Aromatic Ester from Piper longum and Its Analogues Inhibit Expression of Cell Adhesion Molecules on Endothelial Cells $\uparrow$, Biochemistry, 44(48) (2005) 15944-15952.

[12] Natarajan K.S., Narasimhan M., Shanmugasundaram K.R., Shanmugasundaram E.R.B., Antioxidant activity of a salt-spiceherbal mixture against free radical induction, $J$. Ethnopharmacol., 105 (2006) 76-83.

[13] Priya N.., Kumari S., Research Article Antiviral Activities and Cytotoxicity Assay of Seed Extracts of Piper longum and Piper nigrum on Human Cell Lines, Int. J. Pharm. Sci. Rev. Res., 44 (2017) 197-202

[14] Pradeep C.R., Kuttan G., Effect of piperine on the inhibition of lung metastasis induced B16F-10 melanoma cells in mice., Clin. Exp. Metastasis, 19 (2002) 703-708.

[15] Li S., Lei Y., Jia Y., Li N., Wink M., Ma Y., Piperine, a piperidine alkaloid from Piper nigrum re-sensitizes P-gp, MRP1 and BCRP dependent multidrug resistant cancer cells, Phytomedicine, 19(1) (2011) 83-87.

[16] Lee W., Kim K.-Y., Yu S.-N., Kim S.-H., Chun S.-S., Ji J.-H., et al., Pipernonaline from Piper longum Linn. induces ROS-mediated apoptosis in human prostate cancer PC-3 cells, Biochem. Biophys. Res. Commun., 430(1) (2013) 406-412.

[17] Bezerra D.P., Pessoa C., Moraes M.O. de, Alencar N.M.N. de, Mesquita R.O., Lima M.W., et al., In vivo growth inhibition of sarcoma 180 by piperlonguminine, an alkaloid amide from the Piper species, J. Appl. Toxicol., 28 (2008) 599607

[18] Patra J.K., Das G., Fraceto L.F., Campos E.V.R., Rodriguez-Torres M. del P., Acosta-Torres L.S., et al., Nano based drug delivery systems: recent developments and future prospects, $J$. Nanobiotechnology, 16 (2018) 1-33.

[19] Chandran S.P., Chaudhary M., Pasricha R., Ahmad A., Sastry M., Synthesis of Gold Nanotriangles and Silver Nanoparticles Using Aloe vera Plant Extract, Biotechnol. Prog., 22 (2006) 577-583

[20] Sathishkumar M., Sneha K., Won S.W., Cho C.W., Kim S., Yun Y.-S., Cinnamon zeylanicum bark extract and powder mediated green synthesis of nano-crystalline silver particles and its bactericidal activity, Colloids Surfaces B Biointerfaces, 73 (2009) 332-338.

[21] McNamara K., Tofail S.A.M., Nanoparticles in biomedical applications, Adv. Phys. X, 2 (2017) 54-88

[22] Siddiqi K.S., Husen A., Rao R.A.K., A review on biosynthesis of silver nanoparticles and their biocidal properties, J. Nanobiotechnology, 16(1) (2018) 14.

[23] Saifuddin N., Wong C.W., Yasumira A.A.N., Rapid Biosynthesis of Silver Nanoparticles Using Culture Supernatant of Bacteria with Microwave Irradiation, E-Journal Chem., 6 (2009) 61-70.

[24] Kowshik M., Ashtaputre S., Kharrazi S., Vogel W., Urban J., Kulkarni S.K., et al., Extracellular synthesis of silver nanoparticles by a silvertolerant yeast strain MKY3, Nanotechnology, 14 (2003) 95-100.

[25] Marslin G., Siram K., Maqbool Q., Selvakesavan R., Kruszka D., Kachlicki P., et al., Secondary Metabolites in the Green Synthesis of Metallic Nanoparticles, Materials (Basel).,11(6) (2018) 1- 
25.

[26] Rajesh R.W., Jaya L.R., Niranjan K.S., Vijay D.M., Sahebrao B.K., Phytosynthesis of Silver Nanoparticle Using Gliricidia sepium (Jacq.), Curr. Nanosci., 5(1) (2009) 112-117.

[27] Golovine K. V., Makhov P.B., Teper E., Kutikov A., Canter D., Uzzo R.G., et al., Piperlongumine induces rapid depletion of the androgen receptor in human prostate cancer cells, Prostate, 73 (2013) 23-30.

[28] Shin J.-M., Jeong Y.-J., Cho H.-J., Park K.-K., Chung I.-K., Lee I.-K., et al., Melittin Suppresses HIF-1 $\alpha$ /VEGF Expression through Inhibition of ERK and mTOR/p70S6K Pathway in Human Cervical Carcinoma Cells, PLoS One, 8(7) (2013) e69380

[29] Hosseini H., Rajabibazl M., Ebrahimizadeh W., Dehbidi G.R., Inhibiting angiogenesis with human single-chain variable fragment antibody targeting VEGF, Microvasc. Res., 97 (2015) 1318.

[30] Ferrara N., Gerber H.-P., LeCouter J., The biology of VEGF and its receptors, Nat. Med., 9 (2003) 669-676

[31] Semenza G.L., Targeting HIF-1 for cancer therapy, Nat. Rev. Cancer, 3 (2003) 721-732. 